\title{
Alcanzar justicia. El documento del pleito entablado por el obispo de Cartagena de Indias para recuperar el derecho de patronazgo y administración del hospital San Sebastián
}

In search of justice. The dossier of the lawsuit filed by the Bishop of Cartagena to recover the right of patronage and administration of the San Sebastian Hospital

\section{(2) OpenEdition}

\section{Journals}

Electronic version

URL: http://journals.openedition.org/corpusarchivos/3912

DOI: 10.4000/corpusarchivos.3912

ISSN: 1853-8037

\section{Publisher}

Diego Escolar

\section{Electronic reference}

John Jairo Marín Tamayo, « Alcanzar justicia. El documento del pleito entablado por el obispo de Cartagena de Indias para recuperar el derecho de patronazgo y administración del hospital San Sebastián », Corpus [En línea], Vol. 10, №. 2 | 2020, Publicado el 16 diciembre 2020, consultado el 29 diciembre 2020. URL : http://journals.openedition.org/corpusarchivos/3912 ; DOI : https://doi.org/ 10.4000/corpusarchivos.3912

This text was automatically generated on 29 December 2020 . 


\section{Alcanzar justicia. El documento del pleito entablado por el obispo de Cartagena de Indias para recuperar el derecho de patronazgo y administración del hospital San Sebastián}

In search of justice. The dossier of the lawsuit filed by the Bishop of Cartagena to recover the right of patronage and administration of the San Sebastian Hospital

John Jairo Marín Tamayo

\section{EDITOR'S NOTE}

Fecha de recepción del original: 16/03/2020

Fecha de aceptación para publicación: 06/10/2020

\section{Introducción}

Como todos los del período colonial temprano, el hospital San Sebastián de Cartagena de Indias fue proyectado para atender a los pobres y enfermos (Archivo General de Indias (AGI), Santafé 987, L.1, F.71-72). En el momento mismo que el adelantado Pedro de Heredia fundó la ciudad en 1533 y se procedió a la traza, los "peritos medidores señalaron iglesia, dióse plaza y a San Sebastián dos de los mejores Solares, donde hay hospital nombrado" (Castellanos, 1997, p. 706). Sin saber exactamente cuándo se construyó el primitivo hospital de Cartagena, se estima que esto ocurrió entre 1535 y 1536. El edificio se construyó seguramente bajo el impulso del primer obispo de la 
diócesis, el dominico fray Tomás del Toro (1534-1536) que llegó a su sede episcopal no solo con la misión de proveer las iglesias de ella con clérigos y de convertir, instruir y defender a los indígenas, sino también de construir la catedral (AGI, Santafé 987, L. 1, F. 78v) y un hospital para el cuidado de los pobres y enfermos (AGI, Santafé 987, L. 1, F. 71; Urueta, 1912, p. 198). Para la construcción de este último se le concedió, el 21 de mayo de 1534, los relaves y escobillas de las fundiciones de oro y plata y de otros metales que se fundiesen en la ciudad, no solo para el presente, sino también para el futuro (AGI, Santafé 987, L.1, F. 71-72). Pero lo cierto del caso es que el hospital no pudo gozar de esta renta hasta mucho después, pues la casa de fundición de la ciudad no se encontraba en funcionamiento (AGI, Santo Domingo 49, R. 8, N. 57, F. 4v).

Para la segunda mitad del año 1537, la institución ya se encontraba en pleno funcionamiento, como se deduce del informe dado a las autoridades metropolitanas por Juan de Vadillo, oidor de la Audiencia de Santo Domingo quien llegó a Cartagena como juez de residencia de Heredia. Según el oidor, en el hospital se acogían enfermos venidos de Nombre de Dios, de la tierra adentro y de otras partes de la provincia. El primer edificio debió ser un simple bohío en paja y bareque, pues el propio Vadillo, solicitó a la Corona le fueran acordados algunos recursos para hacerle casa y dotarlo de médico que asegurara el cuidado de los enfermos (AGI, Santo Domingo 49, R. 8, N. 57 BIS, F. 10v).

3 En 1538, el segundo obispo de Cartagena, el también dominico fray Jerónimo de Loaysa (1537-1541), solicitó a la Corona que de las penas de cámara se le hiciera merced para hacer un monasterio y para el edificio del hospital, a lo que la Corona respondió concediéndole la dicha merced por tres años consecutivos a partir de ese momento (AGI, Santafé 987, L. 2, F. 61v-62). Aunque Cartagena ya había sido elevada a la dignidad de silla episcopal mediante la bula Illius Fulciti Praedio del 24 de abril de 1534 (Borrego Plá, 1983, p. 448), su institución canónica solo se dio el 28 de junio de 1538. El documento de erección del obispado es de suma importancia, porque en él se precisa que era el obispo quien tenía la potestad de nombrar mayordomo para la entidad hospitalaria, el cual debía "dar todos los años cuenta de los recivos y consumidos al Obispo y al Capítulo, ó a los oficiales para esto especialmente señalados por ellos: también ha de ser elegido y removido á voluntad de ellos habiendo él dado idónea fianza antes que sea admitido á la administración" (AGI, Patronato 1, N. 40, R. 1; Urueta, 1887, p. 115). Ello indica que el hospital estuvo, desde sus inicios, bajo el patronazgo de las autoridades eclesiásticas

Durante el ataque del 24 de julio de 1543, la noche antes de la víspera de Santiago apóstol (AGI, Santafé 62, N. 3; Patronato 197, R. 17, F. 71-72v) perpetrado por corsarios franceses, la ciudad de Cartagena fue saqueada, y tanto la catedral como el hospital sufrieron grandes pérdidas. Consciente de la delicada situación de la ciudad, el 24 de abril de 1545, la Corona otorgó, entre otros auxilios, mil pesos para la catedral, quinientos para el obispo y ochocientos ducados de oro para el hospital, estos últimos pagados a razón de doscientos ducados por año para la compra de camas (AGI, Santafé 987, L. 2, F. 190-193). En ese momento el hospital funcionaba en una casa en la que se podían albergar hasta cincuenta personas entre españoles e indígenas, pero estaba sin huéspedes, como lo señaló en su carta del 24 de julio de 1545 el gobernador Miguel Díaz de Armendáriz (AGI, Patronato 27, R. 21, F. 4v). Luego de haber constatado que en la ciudad no había recursos para cubrir las promesas de la Corona, fray Francisco de Benavides, tercer obispo de Cartagena (1541-1550), en noviembre de 1546, notificó al 
rey de la situación y este pidió a los oficiales de la Casa de la Contratación de Sevilla que enviaran los auxilios a Cartagena y mandó que se le hiciera merced de otros quinientos pesos para el hospital (Santafé 987, L. 2, F. 208v). Al inicio del año siguiente, el rey le otorgó un nuevo auxilio de doscientos pesos de oro para la compra de ropa de cama y otros suministros para el cuidado de los enfermos (Santafé 987, L. 2, F. 212v).

En los años siguientes se puso en marcha un proyecto de construcción del centro, como se deduce de una real cédula del 11 de marzo de 1553. En ella la Corona ordenó a los oficiales de la Casa de la Contratación de Sevilla que le fueran entregados a fray Gregorio de Beteta, electo obispo de la diócesis, seiscientos pesos de oro en bienes de difuntos para "que se haga en la ciudad de Cartagena un hospital donde se recojan los pobres [...] para ayuda a la obra del edificio y para camas y otras cosas necesarias al dicho hospital" (Santafé 987, L. 3, F. 82), lo cual debía gastar en acuerdo con el gobernador y los regidores de la ciudad (Santafé 987, L. 3, F. 82-82v). El auxilio parece que nunca se obtuvo, porque Beteta no llegó a su sede, a la cual había renunciado para septiembre de 1556 (AGI, Indiferente 773, N. 168). La idea de la construcción del hospital no deja de sorprender, porque que se sabe que, aunque la ciudad de Cartagena se incendió en 1552, el hospital quedó en pie y continúo funcionando, además, fue allí que se trasladó el deán y cabildo eclesiástico mientras se reconstruía la catedral (AGI, Santafé 228, N. 11).

6 Poco después de que el cabildo eclesiástico dejó el hospital y se instaló en la reconstruida catedral, el doctor Juan de Maldonado, juez de residencia de Pedro de Heredia y gobernador interino de la provincia (AGI, Patronato, 282, N.1, R. 44), tomó por la fuerza la administración del hospital y la adjudicó al cabildo de la ciudad (AGI, Santafé 228, N. 11). A partir de ese momento, que se estima fue entre el 23 de abril y el 10 de octubre de 1555, tanto el cabildo eclesiástico como el obispo Juan de Simancas (1555-1570) hicieron instancias para recuperar lo que consideraban se les había usurpado, pero no tuvieron éxito en sus gestiones (AGI, Santafé 228, N. 11. F. 11v).

Con el nombramiento en 1574 de Pedro Fernández de Busto como nuevo gobernador de la provincia de Cartagena, un nuevo período se abre para el hospital. El gobernador le dio un gran impulso al desarrollo urbano de la ciudad, y "bajo su gestión se edificó la catedral en un nuevo lugar, se construyeron los edificios de la Aduana y se continuó y agrandó el del hospital de San Sebastián" (Borrego Plá, 1983, p. 272), al cual se le construyeron "dos nuevos cuartos muy suntuosos, uno bajo y otro alto, y una Iglesia" (AGI, Santafé 228, N. 11, F. 21r). Ese momento coincide con la llegada a la ciudad del dominico fray Dionisio de Sanctis como nuevo obispo de la diócesis (1574-1577). Desde su llegada el 18 de diciembre de 1574 (AGI, Contaduría 1380, N. 6. F. 109-112v), el prelado inició su actividad pastoral y, como los decretos del Concilio de Trento lo ordenaban, quiso visitar el hospital San Sebastián, pero los miembros del cabildo de la ciudad se lo impidieron. Mediante carta del 25 de mayo de 1575, el obispo solicitó al rey que se le informara si en dicho caso había o no apropiación de la jurisdicción por parte del cabildo de la ciudad y que se hiciera lo que se debiere hacer (AGI, Santafé 187, L. 2, F. $35 r)$.

8 Sin respuesta a su demanda, dos años más tarde, el obispo recurrió de nuevo al monarca. En esta ocasión, Dionisio de Sanctis no solicitó información alguna, sino que denunció lo que consideraba era una usurpación y dejó claro que el patronazgo y administración del hospital se lo había apropiado el cabildo de la ciudad. En ese orden de ideas, suplicó al rey "dar cédula y provisión real para que se le vuelva la posesión y 
administración del dicho hospital y la tenga según y de la manera que antes que se le quitase la habían tenido los prelados antecesores" (AGI, Santafé 228, N. 11).

Tal vez, considerando que la Corona no se pronunciaría sobre el caso, decidió entablar simultáneamente un pleito ante el gobernador de la provincia contra el cabildo de la ciudad de Cartagena. Para representarlo en el caso, el obispo de Cartagena designó a Bartolomé de Arjona, mayordomo de la fábrica de la catedral, quien el 11 de marzo de 1577 presentó ante el gobernador de la provincia, don Pedro Fernández de Busto, la carta que así lo acreditaba. Además de especificar el alcance del poder dado a su representante, el prelado precisó el propósito del recurso: "pedir la administración y visitación del hospital San Sebastián de esta ciudad de Cartagena, la cual a nos pertenece desde su fundación" (AGI, Santafé 228, N. 11, F. 2r). Como se puede constatar, la demanda reúne en una sola causa los dos problemas planteados por el obispo en sus cartas de 1575 y 1577, es decir, el derecho a visitar el hospital y la recuperación de su patronazgo y administración. Para sustentar su demanda, Dionisio de Sanctis precisó las circunstancias del hecho en los siguientes términos:

El hospital del señor San Sebastián de esta ciudad se ha hecho de limosnas y se ha sustentado de ellas y tiene y ha gastado y gasta es de las dichas limosnas y de legados de testamentos, y como la administración de él y de sus bienes la tuvieron los obispos sus antecesores, y en caso de vacante, el deán y cabildo de esta santa iglesia, hasta que el doctor Juan Maldonado, Juez que fue de residencia en esta ciudad, por fuerza y contra la voluntad del dicho cabildo, se la tomó y se metió a la dicha administración y de cómo los deán y cabildo reclamaron y les requirieron no les usurpase ni tomase la dicha administración, y asimismo el señor obispo don Juan de Simancas requirió se la restituyesen como cosa que a él pertenecía y siempre se ha pretendido por el señor obispo, deán y cabildo y de derecho les pertenece (AGI, Santafé 228, N. 11. F. 1r).

Hernando de las Alas, procurador general de la ciudad, recibió copia de la demanda del obispo el 23 de marzo de 1577, dando inicio a un importante pleito civil entre les autoridades civiles y eclesiásticas de la ciudad de Cartagena. En su respuesta, el procurador alegó que la demanda no procedía porque el obispo no dio los lotes para la fundación del hospital, porque ni él ni sus antecesores fundaron el hospital ni compraron sitio ni suelos donde se fundase y porque tampoco lo habían dotado. Apunta el procurador que quien fundó el hospital fue la ciudad que, además, señaló el sitio donde debía construirse, lo que para el procurador probaba que el patrón y administrador del hospital era el cabildo de la ciudad y no el obispo. Subraya que, si en algún momento el obispo tuvo la administración, fue cuando el cabildo eclesiástico se trasladó al hospital a causa del incendio de la ciudad y de la catedral en 1552, pero cuando esta fue reconstruida dejaron el hospital y el cabildo de la ciudad retomó su administración. Como patrón y administrador del hospital, el dicho cabildo siempre procuró aumentar la renta y los haberes del hospital y para ello persuadían a vecinos y forasteros enfermos de hacer mandas en su favor. Añadió que los difuntos que habían dejado sus bienes al hospital, lo habían hecho a condición de que el cabildo de la ciudad fuera siempre su patrón y administrador y que, si su voluntad no fuera respetada, revocarían sus mandas. Sostiene, además, que el prelado no tiene nada que reclamar porque ni los obispos ni los clérigos han favorecido al hospital con limosnas y porque el cabildo de la ciudad es quien tiene el patronazgo y administración del hospital en nombre del rey quien ha auxiliado el hospital con mercedes y limosnas (AGI, Santafé 228, N. 11, F. 5v-8v). 
11 En su respuesta, el procurador de la ciudad ignora prácticamente que los obispos hubieran ejercido el patronazgo y administración del hospital desde su fundación hasta 1555, como estaba plasmado en el documento de erección del obispado. Cabe notar que en su respuesta y durante el pleito, Hernando de las Alas nunca hizo alusión a la acción de Maldonado, que era el hecho sobre el cual el obispo apoyaba su demanda.

El 11 de abril de 1577 todo estaba dispuesto para dar inicio a las audiencias en las que fueron escuchados los testigos de ambas partes. Para interrogar a sus testigos, Bartolomé de Arjona preparó un cuestionario de nueve preguntas; mientras que Hernando de Alas utilizó un cuestionario dos veces más largo. Cada parte presentó cinco testigos; en primer lugar, se escucharon las declaraciones de los testigos del demandante $\mathrm{y}$, pocos días más tarde, fueron llamadas a testimoniar las personas designadas por el procurador del cabildo de la ciudad. En las audiencias, que tuvieron lugar entre el 11 de abril y el 20 de mayo de 1577, se escuchó el testimonio de diez hombres, todos ellos vecinos de la ciudad y, en la mayoría de los casos, con pasado administrativo en lo civil o en lo eclesiástico.

Recuperando el patronazgo y administración del hospital, Dionisio de Sanctis aspiraba a contribuir a la salvación de las almas de los pobres que allí eran recluidos, pues, en el siglo XVI, la salud y la enfermedad fueron problematizados desde la perspectiva escatológica. Los hospitales "se concentraron en atender no solamente las dolencias del cuerpo, sino también las espirituales, buscando al final la salvación del alma" (Rivera, 2012, p. 90); la enfermedad era vista como una oportunidad de salvación. Con la acción interpuesta, el obispo de Cartagena no solo pretendió dar a la Iglesia el sitio que le correspondía en la sociedad colonial, sino también, y fundamentalmente, ejercer el poder que le correspondía como pastor de una iglesia local que comenzaba a implantarse en un régimen colonial.

14 El expediente del pleito, que ha llegado hasta nosotros, no va más allá de las declaraciones tomadas a los testigos, lo que indica que no contiene, si es que la hubo, la sentencia final, lo cual tampoco ha sido posible confirmar a través de otras fuentes documentales. Todo parece indicar que, luego de las audiencias, el gobernador no tomó ninguna decisión, o al menos no se publicó, y como el obispo murió el 9 de septiembre del mismo año todo quedó como estaba. Su sucesor, el también dominico fray Juan Montalvo, en carta del 25 de enero de 1581, solicitó exactamente lo mismo que había solicitado Dionisio de Sanctis (Friede, tomo VIII, 1976, p. 34), lo que indica que este no tuvo éxito en su empresa. De hecho, el nuevo obispo afirmó claramente que la administración del hospital pertenecía por derecho común y por el Concilio Tridentino a los obispos (Friede, tomo VIII, p. 34). Para el obispo Montalvo la solución al problema debía venir del monarca, ya que este tenía la autoridad suficiente para devolver el patronazgo del hospital a los obispos o bien, yendo contra la Iglesia romana, contra el derecho y contra la legislación tridentina, dejar las cosas como estaban, lo cual estimaba no era beneficioso para la institución hospitalaria (Friede, tomo VIII, p. 34).

La lucha por el patronazgo y la administración del hospital San Sebastián de Cartagena debió resolverse definitivamente en junio de 1589 con la publicación de las llamadas Ordenanzas del Cabildo de Cartagena que incluyeron las ordenanzas para el gobierno del hospital (Urueta, 1887, pp. 209-212). Allí quedó establecido que el cabildo de la ciudad era el titular del derecho de patronazgo y administración del hospital, derecho que ejerció hasta 1596. Ese año, por deseo expreso del rey, el cabildo cedió el cuidado de los 
enfermos a los hermanos de San Juan de Dios, que en 1612 se hicieron cargo de todos sus bienes y rentas (Borrego, 1983, p. 17).

\section{El manuscrito y los criterios de transcripción}

El manuscrito original del expediente del pleito interpuesto por el obispo Dionisio de Sanctis para recuperar la posesión y administración del hospital de San Sebastián está custodiado en el Archivo General de Indias (AGI) y hace parte del legajo 228 del fondo Audiencia de Santa Fe y cuya asignatura completa es Santa_fé 228, N. 11. El documento está compuesto de 39 folios, todos escritos en reto y verso, tal como el escribano público, Juan de Meneses, lo dejó establecido en las notas de autentificación del documento: "Lo hice escribir en tal treinta y nueve folios de papel y en fe de ello lo hice con mi signo" (AGI, Santafé 228, N. 11. F. 39v). Según nuestras investigaciones, el dicho expediente aún no ha sido editado, ni ha sido objeto de estudios académicos, por ser poco conocido de los especialistas o por no haber suscitado su interés. Se accedió al documento a través de una petición hecha al AGI en junio de 2016, en la cual se solicitó una copia digitalizada del legajo 228 del fondo Santafé, para adelantar una investigación sobre el obispo de Cartagena, y en dicho material se encontró el expediente que hoy es objeto de la transcripción que aquí se ofrece. Dado que el trabajo se realizó a través de la copia digital, se puede afirmar que el documento original se encuentra en buen estado de conservación y no presenta pérdida de información por falta de folios, roturas o manchas. Está redactado de la mano de un único amanuense y en letra procesal, bastante uniforme, pero con una separación irregular de las palabras y un constante ligado de la escritura (Muñoz, 1880, p. 57). Las enmiendas son muy pocas y están precisadas en la parte baja de los folios correspondientes.

17 Aunque en el manuscrito original no hay separaciones entre los distintos documentos que componen el expediente, en la transcripción que aquí se propone se introdujeron separaciones entre ellos y para eso se han añadido algunos títulos, colocados entre corchetes, para diferenciar los unos de los otros. En primer lugar, se observa la carta de poder otorgada por Dionisio de Sanctis, el 26 de febrero de 1577, a Bartolomé de Arjona para representarlo en el pleito ( 6 folios). Seguidamente, se encuentran las preguntas del interrogatorio preparado por Arjona para interrogar a sus testigos ( 3 folios). A continuación, se ubica la notificación hecha, el 23 de marzo, a Hernando de las Alas, quien como procurador general de la ciudad, representó al cabildo secular en el caso (1 folio). Sigue la respuesta de Hernando de las Alas a la petición presentada por Bartolomé de Arjona, la cual se le dio a conocer el 26 de marzo del mismo año ( 7 folios). Luego aparece la notificación y la respuesta que el 28 de marzo Bartolomé de Arjona dio a la notificación que le había sido hecha el 26 de ese mismo mes (2 folios). Enseguida se percibe la probanza del señor obispo, la cual está conformada por los testimonios de los canónigos Juan Campos y Antonio Verdugo, del capitán Francisco Sánchez, de Juan Sánchez Mejía y del arcediano Francisco Hernández (18 folios). Inmediatamente están las preguntas del interrogatorio preparado por Bartolomé de Arjona para interpelar a sus testigos (8 folios). Sigue la probanza de los procuradores del cabildo de la ciudad, la cual está conformada por los testimonios de Pedro Mejía Mirabal, Gonzalo Hernández, Bartolomé Sánchez, Lorenzo Martín y Francisco Dalva (32 folios). Finalmente, se encuentran las notas de autentificación y datación del documento (1 folio). 
18 Sin desconocer el valor de las transcripciones paleográficas, se ha optado en este caso por la transcripción modernizada (Tanodi, 2000, p. 261) que respeta fielmente el contenido del manuscrito original, pero se moderniza la ortografía y la puntuación con el fin de facilitar su lectura, tanto por especialistas como por neófitos. Para la transcripción se adoptaron los siguientes criterios. Se mantuvo el orden que presentan los documentos en el expediente. Se modernizó y homogenizó la grafía, la ortografía, la puntuación, la acentuación y el uso de las mayúsculas siguiendo el uso actual, lo cual se aplicó también a los nombres propios y apellidos de personas. Se desarrollaron las abreviaturas por suspensión y contracción y se actualizó su ortografía; cuando la interpretación ha causado dudas, se pone un signo de interrogación entre corchetes después de la abreviación, lo cual se aplicó también a todas las palabras de interpretación dudosa. Cuando fue necesario añadir un signo de puntuación, se hizo para restituir el sentido de la frase, siempre y cuando no hubiera peligro de desvirtuar el significado de la misma. Se separaron las palabras que, en su grafía origina, representaban una sola palabra como por ejemplo: deesta, deste, desto, destas, della, dello, dellas dellos, ques, quel. Fueron conservadas aquellas palabras que aparecen tachadas en el texto, al igual que la nota que indica la enmienda al final del folio. Cuando el escribano omite una palabra que pueda deducirse del contexto de la frase, esta se añade entre corchetes; ello se aplica igualmente en el caso que falte una o dos letras, como es el caso de la letra $\mathrm{S}$ que se añade para formar los plurales cuando se ha requerido. Como en ocasiones una palabra puede iniciar en un folio y terminar en el siguiente, el cambio de folio se indicará en medio de una palabra que se desarrolla entre los dos folios. Las palabras claramente escritas, pero de forma incorrecta o incomprensibles, se transcriben colocando tras la palabra el signo sic entre corchetes. Las expresiones en latín se conservan en dicho idioma y se transcriben en cursiva. Las firmas se señalan con [rubricado] al lado del nombre y en el caso de las rúbricas sin firma hemos utilizado la palabra [rúbrica]. No se indica la separación interlineal, pero sí el cambio de folio. Cabe destacar que la numeración de los folios del manuscrito original se ha hecho en el reverso de los mismos y se termina en el folio 22. Dada esta particularidad, y para facilitar la ubicación de la información en el expediente, se ha optado por enumerar la totalidad de los folios, el número aparece entre corchetes aclarando si es reto ( $r$ ) o verso (v). En la transcripción se han incorporado separaciones para identificar los diferentes documentos que componen el expediente según se anotó anteriormente, los títulos de dichos documentos van en negrita y entre corchetes para indicar que son añadidos por el editor.

\section{Transcripción del manuscrito}

[En borde superior derecho: 20-3-1577]

[Carta de poder dada a Bartolomé de Arjona]

[1r] En la muy noble y muy leal ciudad de Cartagena de las Indias, costa de Tierra Firme, a once días del mes marzo de mil y quinientos y setenta y siete años, ante el muy ilustre señor Pedro Fernández de Busto, gobernador y capitán general, y por ante mí, el escribano yuso escrito, pareció presente Bartolomé de Arjona, vecino de esta dicha ciudad en nombre del muy ilustre reverendísimo señor obispo de este obispado, y presentó la petición y poder siguiente. 
Muy ilustre Bartolomé de Arjona, vecino de esta ciudad en nombre del muy ilustre y reverendísimo señor don fray Dionisio de Sanctis, obispo de este obispado de cuyo poder hago presentación, parezco ante vuestra merced y digo que a su señoría reverendísima y a la preeminencia de su pontifical jurisdicción conviene hacer una información ad a perpetuam rei memoriam de cómo el hospital del señor San Sebastián de esta ciudad se ha hecho de limosnas y se ha sustentado de ellas y tiene y ha gastado y gasta es de las dichas limosnas y de legados de testamentos, y de cómo la administración de él y de sus bienes la tuvieron los obispos sus antecesores, y en caso de vacante, el deán y cabildo de esta santa Iglesia, hasta que el doctor Juan Maldonado, juez que fue de residencia en esta ciudad, por fuerza y contra la voluntad del dicho cabildo, se la tomó $[1 \mathrm{v}]$ y se metió a la dicha administración y de cómo los deán y cabildo reclamaron y les requirieron no les usurpase ni tomase la dicha administración, y asimismo el señor obispo don Juan de Simancas requirió se la restituyesen como cosa que a él pertenecía y siempre se ha pretendido por el señor obispo, deán y cabildo y de derecho les pertenece.

Pido y suplico a vuestra merced los testigos que presentare los mande a examinar por el tenor de este interrogatorio que presento y lo que expusieren y declararen se me dé firmado y signado en pública forma, en manera que haga fe y en él vuestra merced si fuere necesario ponga su autoridad y decreto judicial y pido se mande a tal a Hernando de las Alas, procurador general de esta ciudad, y a Juan de Baena, mayordomo del dicho hospital, para hacer la dicha información y para ello pido justicia.

Sepan cuantos esta carta de poder vieren cómo nos, don fray Dionisio de Sanctis del consejo de su majestad, obispo de este obispado de Cartagena de las Indias, en la forma que mejor haya lugar de derecho, otorgamos y conocemos que damos y otorgamos todo nuestro poder cumplido, libre y llenero y bastante, según que lo nos habemos [2r] y tenemos, y de derecho más puede y debe valer a vos Bartolomé de Arjona, mayordomo de la fábrica de la santa iglesia catedral de esta ciudad de Cartagena y vecino de esta dicha ciudad, especialmente para que por nos y en nuestro nombre y como yo mismo, representando mi propia persona, podáis parecer y parezcáis ante Su Majestad y señores de su Real Consejo de Indias y otros cualesquier señores jueces y justicias de $\mathrm{Su}$ Majestad y pedir la administración y visitación del hospital de San Sebastián de esta ciudad de Cartagena, la cual a nos pertenece desde su fundación, y sobre ello hacer cualesquier informaciones a perpetuam rei memoriam y otras cualesquier que convengan, $\mathrm{y}$ hacer cualesquier pedimento $\mathrm{y}$ requerimiento $\mathrm{y}$ todas las otras diligencias hasta haber cumplido y seto (sic) nuestra pretensión convengan y se requieran y sean necesarias. $Y$ otrosí no derogando la especialidad a la generalidad, ni menos por el contrario vos, damos el dicho nuestro poder cumplido generalmente para en todos nuestros pleitos y causas, así en demandando como en defendiendo que nos tenemos y esperamos tener con cualesquier personas, iglesias y universidades [2v] y comunidades y las tales contra nos y para que en razón de lo que debes, podáis parecer y parezcáis ante la dicha Real Majestad y señores de su Consejo de Indias y otros cualesquier jueces y justicias y eclesiásticos y seglares de cualquier jurisdicción que sean, y ante ellos y cualesquier de ellos pedir y demandar, responder negocios, conocer requerir y protestar, convenir y reconvenir y jurar en mi ánima cualesquier juramentos necesarios de verdad decir y los pedir y desdecir en las otras parte y partes y presentar testigo y escrituras y probanzas $\mathrm{y}$ otro cualquier género y manera de prueba y sacar cualesquier escrituras y testimonio de poder de cualesquier personas y escribanos en cuyo poder estén y los presentar en 
juicio y ver, presentar, jurar y conocer todo lo que contra mí se presentare, el otorgar y contradecir y pedir publicaciones y conciliaciones y restituciones y hacer cualesquier recusaciones de jueces y escribanos, y las jurar y os apartar de ellas siendo necesarios pedir y oír sentencias interlo [3r] cutorias y definitivas y consentir las que fueren en nuestro favor, y apelar y suplicar de las que fueren en contrario y lo seguir y dar quien lo siga y pedir tasación de costas, jurarlas y recibirlas y dar cartas de pago de ellas y sacar y ganar de Su Majestad y de Su Santidad cualesquier mercedes, cédulas y bulas y mandamientos, de acusaciones, de cualesquier excomuniones en que hayamos caído, incurrido simplemente $a$ ad cautelam y en otra cualquier manera y presentar las tales cédulas, mandamientos y provisiones reales y las hacer intimar y notificar y presentar en juicio con otros cualesquier recaudos y testimonios y pedir ejecuciones pregones, prisiones, ventas y remates de bienes y tomar posesión de los bienes ejecutados y pedir ser en ellos amparado y defendido conforme a derecho, podáis hacer y hagáis todos los otros autos judiciales y extrajudiciales que convengan y sean necesarios, y todo lo que nos haríamos y hacer podríamos presente siendo que cuán cumplido y bastante poder para lo que debes, hemos y tenemos otro tal y tan cumplido, y ese mismo los damos y otor [3v] gamos a vos, el dicho Bartolomé de Arjona con todas sus incidencias y dependencias, anexidades y conexidades, y con libre y general administración y faculta[d] entera de sustituir este poder en uno y más procuradores, y aquellos revocar y otros de nuevo crear, con semejante y limitada facultad, quedando en vos todavía el poder y cargo principal, para los cuales y a vuestros sustitutos y a vos relevamos según forma de derecho y so la cláusula del y para lo haber por firme, obligamos nuestras personas y bienes espirituales y temporales, muebles y raíces, habidos y por haber, en testimonio de lo cual otorgamos la presente carta que es hecha en la ciudad de Cartagena de las Indias en las casas de la morada de su señoría reverendísima, a veinte y seis días del mes de febrero de mil y quinientos y setenta y siete años, siéndolo el señor deán don Juan Fernández y Martín Pérez, notario apostólico, y el canónigo Juan de Campos, vecinos de esta ciudad y su señoría reverendísima, a quien yo, el escribano, conozco, lo firmo de su nombre, fray Dionisio Cartaginesis, pasó ante mí. Juan de Meneses. Escribano.

[Preguntas del interrogatorio preparado por Bartolomé de Arjona]

[4r] Yo, Juan de Meneses, escribano de Su Majestad y mayor de esta gobernación de Cartagena y público del número de esta gobernación y ciudad, fui presente y lo hice escribir e hice aquí mismo en testimonio de verdad. Juan de Meneses. Escribano.

1. Primeramente, si conocen al reverendísimo señor obispo don fray Dionisio de Sanctis y a mí, dicho Bartolomé de Arjona, y si conocieron al doctor Juan Maldonado, juez de residencia que fue de esta provincia, y si conocen a Hernando de las Alas, procurador general de esta ciudad, y a Juan de Baena, mayordomo del dicho hospital.

2. Ítem, si saben éstos que todas las semanas del año, todos los domingos se echa en la santa iglesia de esta ciudad por el cura y sacristán de ella la limosna del hospital y nombrado personas para que la pidan y lo que así se llega se acude al dicho hospital y al mayordomo, digan lo que sabe.

29 3. Ítem, si saben, vieron, oyeron decir que la renta de posesiones y censos que el dicho hospital tiene es de legados que las buenas gentes que han muerto lo han hecho así, como Hernando de Lipar y fulano Vásquez, difuntos, y otras personas, digan lo que saben. 
30 4. Ítem, si saben que ninguna persona [4v] lega en vida, le ha hecho donación al dicho hospital de ninguna cosa sino que su primera fundación fue de limosnas y de ellas se ha sustentado y sustentan, digan lo que saben.

31 5. Ítem, si saben, vieron, oyeron decir que la administración del dicho hospital siempre la tuvieron los señores obispos fray Francisco de Benavides y fray Jerónimo de Loaiza, siendo obispos de este obispado, y después en sede vacante mucho tiempo, el deán y cabildo, digan lo que saben.

6. Ítem, si saben, vieron, oyeron decir que los dichos señores obispos y el deán y cabildo en sede vacante elegían mayordomo para el dicho hospital y les tomaban y mandaban tomar cuentas, y cuando el dicho doctor Juan Maldonado vino a esta ciudad por juez de residencia, el dicho deán y cabildo de esta santa Iglesia tenía la administración del dicho hospital y puesto por mayordomo de él a Diego Polo, vecino de esta ciudad, y se le tomaron cuentas por los dichos deán y cabildo, digan lo que saben.

7. Ítem, si saben, vieron, oyeron decir que dicho doctor Juan Maldonado, contra la voluntad de los dichos señores deán y cabildo y forzadamente, tomó la [5r] dicha administración y se la dio al cabildo y regimiento de esta ciudad, y aunque por el deán y cabildo se le requirió no se la usurpase, no proveyó nada ni quiso dársela, digan lo que saben.

8. Ítem, si saben que el señor obispo, don Juan de Simancas, requirió a la Justicia y regimiento de esta ciudad sobre lo susodicho por muchas veces en el tiempo que fue obispo de este obispado y no hubo remedio que se le devolviese la dicha administración, digan lo que saben.

9. Ítem, si saben que todo lo susodicho es pública voz y fama. Bartolomé de Arjona.

El señor gobernador mandó dar traslado al cabildo y regimiento de esta ciudad y dentro del tercer día respondan, y con lo que dijeren o no se proveerá justicia, testigo Jerónimo Sotomayor y Mancio de las Cuevas, Pedro Fernández de Busto. Juan de Meneses. Escribano.

[Al margen: Notificación] [a Hernando de las Alas]

Y luego fue notificado por mí, el presente escribano, la petición y proveí mandamiento del señor gobernador a Hernando de las Alas, procurador general de esta dicha ciudad en su persona, siendo testigos Mateo Hernández de Angulo y Francisco Gutiérrez. Juan de Meneses. Escribano. setenta y siete años, [5v] ante el muy ilustre señor gobernador y capitán general y por ante mí, el escribano yuso escrito la presentó el contenido.

[Respuesta de Hernando de las Alas a la petición de Bartolomé de Arjona]

41 Muy ilustre señor Hernando de las Alas procurador general de esta ciudad, digo que vuestra merced mandó dar traslado al cabildo de una petición presentada por Bartolomé de Arjona en nombre del muy ilustre y reverendísimo don fray Dionisio de Sanctis, obispo de esta gobernación, por la que pide se le reciba cierta información y quiere averiguar que la administración del hospital de esta ciudad y sus bienes le pertenece o no al cabildo, lo cual no ha lugar por lo siguiente:

42 Lo uno, porque el dicho señor obispo no es parte en lo que pretende porque a aquel es el patrón que funda alguna iglesia u hospitales y el que da sitio y suelo donde se funde o el que la dota. El dicho señor obispo, ni los obispos pasados, no fundó ni fundaron el 
dicho hospital, ni compraron sitio ni suelo donde se fundase, ni lo dotaron luego de primo ad ultimum, bien se signe, que no es patrón ni administrador.

Lo otro, porque esta ciudad fundó e hizo el dicho hospital y le dio y señaló sitio particular desde que se hizo y así el patrón y administrador es dicho cabildo y no el señor obispo, como pretende.

[6r] Lo otro, porque si el señor obispo se quiere aprovechar diciendo que en algún tiempo tuvieron la administración del dicho hospital los clérigos y dignidades de la santa Iglesia, fue porque cuando se quemó este pueblo, se quemó asimismo la iglesia mayor y porque el dicho hospital quedó en pie, se pasó la iglesia catedral al dicho hospital, entre tanto que se reedificó, porque luego se volvieron a ella y dejaron al dicho hospital según y como estaba primero y volvió el dicho cabildo a continuar la posesión en que estaba y administrando como solía.

Otro, si quiere decir el dicho señor obispo que en la iglesia mayor de esta ciudad se nombran los domingos personas que pidan limosna para el sustento del dicho hospital, esto se hace de poco tiempo a esta parte que antes no lo hacían ni aun consentían los dichos clérigos que se hiciese, antes el Cabildo o el mayordomo del dicho hospital nombraban quien pidiese la dicha limosna y tenían cuidado, como siempre lo han tenido, de sustentar el dicho hospital y curar los pobres que a él concurren.

Lo otro porque el cabildo de esta ciudad, allende de ser patrón y administrador [6v] del dicho hospital, siempre procuraba aumentar la renta y propios de dicho hospital, persuadiendo a los vecinos y forasteros enfermos le hagan mandas representándoles su necesidad y otros justos respetos.

47 Lo otro, el cabildo procura y da orden como en el dicho hospital se curen todos los enfermos que en esta ciudad hay y vienen de los reinos de España en las flotas y armadas de Su Majestad, y de la ciudad de Nombre de Dios y de otras partes, y para tantos gastos no bastaría la renta y propios que el dicho hospital tiene si los gobernadores y cabildo no pusiesen particular cuidado en buscarlo como lo buscan y tienen médico y cirujano salariado, y botica donde se receta y provee todo lo necesario para el dicho hospital.

48 Lo otro, porque los difuntos que han dejado la mayor parte al dicho hospital ha sido con condición que el cabildo de esta ciudad sea siempre patrón y administrador, y que no entre cosa alguna en poder de los clérigos de la santa Iglesia, y por el mismo caso que dejase de ser patrón el dicho cabildo, y se entrometan el señor obispo y los clérigos, [7r] revocan las mandas que así tienen hechas, todo porque los difuntos vieron y entendieron el gran cuidado que los gobernadores y cabildo han tenido de dicho hospital en curar los pobres y enfermos, regalarlos y darles todo lo necesario.

49 Lo otro, porque siendo el dicho cabildo patrón y administrador, como lo es, del dicho hospital, tienen cuidado los vecinos y moradores de esta ciudad de acudir con sus limosnas muy ordenadas y visitar los pobres y consolarlos.

50 Lo otro, porque no solamente el cabildo fundó el dicho hospital y lo hizo a costa suya y de los demás vecinos, más también el dicho solar es donde se han edificado casas que el dicho hospital ha dado a censo que es patrimonio suyo particular, dado y procurado por vuestra merced y cabildo y los demás gobernadores, y no se hallará que este patrimonio que el dicho hospital tiene hayan dado los señores obispos ni clérigos parte alguna al dicho hospital. 
51 Lo otro porque dicho cabildo desde que fundó el dicho hospital ha usado del derecho de patronazgo que tiene, nombrando mayordomo todos los años de mucha fidelidad y cristiandad y les ha tomado la cuenta [7v] así del patrimonio y renta que tiene como de las limosnas que se hacen, sin que el señor obispo ni los demás sus antecesores hayan inquietado ni perturbado a esta posesión en que está el dicho cabildo.

52 Lo otro porque el edificio que ahora se ha hecho para el dicho hospital y la iglesia, y enfermería y aposentos se ha edificado por vuestra merced y con acuerdo del cabildo como patrón, en lo cual se ha gastado mucha suma de pesos de oro y se ha cavado y hecho, con tanta curiosidad, que no hay otra mejor cosa y edificio de hospital desde aquí a Lima, en lo cual así mismo puso mucho cuidado Diego Daza, mayordomo que fue el año que dicho hospital se hizo, y después de acabado se tomó de nuevo posesión de él por Su Majestad Real y por el dicho cabildo en su nombre y se esculpieron las armas en él de esta ciudad y las de vuestra merced en señal de que son los legítimos administradores y patrones del dicho hospital.

Lo otro, porque se vea y entienda que el dicho señor obispo no tiene derecho alguno a lo que pretende averiguar, por información que no solamente los señores obispos [8r] pasados ni clérigos no han favorecido al dicho hospital con sus limosnas y visitas, más aun no han querido ni querrán enterrar los pobres que morían en el dicho hospital, ni decirles misa, lo cual era causa que se enterrasen los difuntos en un lugar muy deshonesto y sucio que estaba junto al hospital, antes que hiciesen la iglesia que está hecha ahora en el hospital.

54 Lo otro, porque siendo el cabildo de esta ciudad patrón administrador, como lo es, del dicho hospital, la superioridad y señorío Su Majestad Real del Rey don Felipe nuestro señor que también ayuda y ayudado con sus limosnas y mercedes, que siempre hace, y a él como a señor le pertenece el derecho de patronazgo, del todo lo es el dicho hospital anexo, lo cual cesaría si el dicho señor obispo tuviese el patronazgo y administración del dicho hospital.

Lo otro, porque aunque esta ciudad no tuviera el título y derecho de patronazgo que tienen el dicho hospital, por estar en posesión como está de tanto tiempo a esta parte, lo hubiera ganado por prescripción.

56 A vuestra merced pido y suplico y con el acatamiento que debo, requiero mande recibir información que estoy pres [8v] to de dar de todo lo en esta petición contenido, y que si la que el señor obispo se ha ofrecido a dar la diere, se le dé juntamente con la que yo, en nombre de esta ciudad, me ofrezco a dar, y no la una sin la otra, porque donde se quiere aprovechar de su información para lo que pretende, se halle la contradicción y justas razones que esta ciudad tiene para que se le conserve y guarde su derecho, para lo cual y en lo necesario, etcétera. Hernando de las Alas, el licenciado Salazar.

57 El señor gobernador mandó dar traslado a la otra parte y a la primera audiencia respondan, testigo: Juan Batista de Segura y Rodrigo Hernández. Juan de Meneses. Escribano.

[Al margen: Notificación] [a Bartolomé de Arjona]

En veinte y seis de marzo, y del dicho año se notificó la susodicha a Bartolomé de Arjona en su persona, testigo: Juan de Ortega y Francisco Gutiérrez, Juan de Meneses, Escribano. que Hernando de las Alas es procurador general de esta ciudad este año, elegido en 
Cabildo por los señores Justicias y Regimiento y Mancio de las Cuevas, es procurador de los pleitos del dicho cabildo, nombrado por dichos [9r] señores y para que conste de ello de pedimento de Mancio de las Cuevas di la presente, hecha en Cartagena a doce días del mes de abril de mil y quinientos y setenta y siete años. Francisco Dalva. días del mes abril del dicho año de mil y quinientos y setenta y siete años, el dicho Bartolomé de Arjona, en nombre del señor obispo, presentó por testigo al canónigo Juan de Campos, canónigo de la santa iglesia de esta ciudad del cual recibí juramento y se lo hizo inforos a sacerdotis y prometió de decir verdad y siendo preguntado por el tenor del dicho interrogatorio y preguntas de él, dijo lo siguiente:

73 1. A la primera pregunta dijo que conoce y conoció a los contenidos, y en la pregunta de vista, trato y conversación, por que es antiguo en esta tierra y a que reside en ella treinta y seis años.

Corpus, Vol. 10, Nº. 2 | 2020 
de Loaiza vio el testigo que el dicho obispo tenía la administración del dicho hospital y ponía capellanes y mayordomos en él, y libraba en las limosnas del hospital y esto debió de ser como cuatro o cinco años, poco más o menos, que fue el tiempo que estuvo en esta ciudad por tal obispo el dicho don Jerónimo de Loaiza, y esto sabe y asimismo en sede vacante de obispo tuvo la dicha adminis [En pie de página: va tachado/ Hernando / no vale] [11r] tración el cabildo de la santa iglesia así como la tenía el dicho obispo y libraban las dichas limosnas [a] los mayordomos que eran, y ponían oficiales en el dicho hospital de capellán y mayordomo y enfermero, hasta que vino el doctor Maldonado y lo quitó por fuerza y se tomó el dicho doctor Maldonado la administración al tiempo que vino por juez de residencia, y después acá se ha quedado la administración del dicho hospital en el cabildo y regimiento de esta ciudad, que puede haber más [de] diez y seis años poco más o menos.

79 6. A la sexta pregunta dijo que dice lo que dicho tiene y que es verdad y este testigo vio que a la sazón que vino a esta ciudad el dicho el doctor Maldonado, era mayordomo del hospital el capitán Diego Polo, puesto por el deán y cabildo en sede vacante, y le tomaron la cuenta por el dicho cabildo de la iglesia de lo que era a su cargo y había gastado como tal mayordomo de dicho hospital, y que es verdad y pasó así todo lo contenido en la pregunta por haberse hallado presente a ello como uno de los prebendados que a la sazón era y al presente es en esta santa iglesia.

80 7. A la séptima pregunta dijo que [11v] dice lo que dicho tiene en la dicha quinta y que es verdad y pasó como la pregunta presente lo declara y sobre ello hubo descomuniones y todavía se quedó con la administración el dicho cabildo de la ciudad y el dicho doctor Maldonado que la gobernaba como juez de residencia.

81 8. A la octava pregunta dijo que este testigo se acuerda haber pasado lo contenido en la pregunta entre el obispo don Juan de Simancas y el cabildo y regimiento de esta ciudad, y nunca hubo remedio de restituir al dicho obispo la dicha administración. 

que este testigo está en esta tierra, nunca ha oído ni visto que ninguna persona estando sano le donase ni diese en vida ninguna hacienda a este dicho hospital y siempre ha oído decir que su fundación fue de limosnas y que el día de hoy el dicho hospital que se encomienda en la iglesia mayor, por mandado de su señoría y esto es lo que sabe y responde de la pregunta.

5. A la quinta pregunta dijo este testigo que cuando a este pueblo vino que habrá los veinte y cinco años, poco más o menos, que dicho tiene en las preguntas antes de esta, al tiempo y sazón que en esta ciudad saltó de los reinos de Cas [13r] tilla, era mayordomo del hospital de esta ciudad el capitán Diego Polo en nombre del deán y cabildo que a sazón era sede vacante y después lo fue otros tres años más hasta que vino el doctor Maldonado y sabe este testigo que el deán y cabildo administraba y regía y gobernaba y tomaba cuentas a los mayordomos que eran del hospital, y asimismo sabe este testigo y vio quejarse al deán don Juan Pérez Materano y el canónigo Juan de Campos que el dicho doctor, con fuerza de gobernador, les usurpaba la dicha administración del dicho hospital y el cabildo secular se hacían patrones y así ha visto después acá que a más de quince años que por fuerza tiene la dicha administración aunque les han sido hechos muchos requerimientos por el obispo don Juan de Simancas y por el deán y Cabildo, y por evitar pasiones lo han disimulado hasta ahora, y ha oído decir públicamente que el obispo don Francisco de Benavides y don Jerónimo de Loaiza obispos, que fueron de este obispado en tiempo del adelantado don Pedro de Heredia, 
fundador de la provincia, fueron patrones del hospital siempre y esto es lo que sabe de esta pregunta.

[13v] 6. A la sexta pregunta dijo que sabe este testigo lo en la pregunta contenido porque a la sazón que vino el dicho doctor Maldonado estaba este testigo en esta tierra y era entonces mancebo lego, y seguía a esta santa iglesia porque pretendía ser clérigo, y a esta la dicha, sabía los negocios tocantes a esta iglesia y hospital, y así sabe este testigo, como arriba tiene dicho, lo en la pregunta contenida antes de esta y eso es lo que sabe.

7. A la séptima pregunta dijo que sabe que el dicho doctor Maldonado sin voluntad y por la fuerza del dicho deán y cabildo tomó la administración del dicho hospital y la dio al cabildo y regimiento de esta ciudad como dicho tiene hasta ahora, la poseen por fuerza y esto es lo que sabe.

8. A la octava pregunta dijo que la sabe porque vio hacer los dichos requerimientos al dicho obispo don Juan de Simancas y que no aprovechó cosa ninguna, y esto es lo que sabe de esta pregunta.

9. A la novena pregunta dijo que lo que dicho tiene es la verdad y lo que sabe para el juramento que hecho tiene, y firmó de su nombre el canónigo Antonio de Verdugo. Ante mí, Juan de Meneses. Escribano.

[Testimonio del capitán Francisco Sánchez]

[14r] Y después de lo susodicho en la dicha ciudad de Cartagena a quince días del mes de abril del dicho año, el dicho Bartolomé de Arjona presentó por testigo al capitán Francisco Sánchez, vecino de esta Gobernación del cual recibí juramento sobre la señal de la cruz y prometió de decir verdad y siendo preguntado por el tenor del dicho interrogatorio y preguntas de él, dijo lo siguiente:

97 1. De la primera pregunta dijo que conoce al señor obispo de esta ciudad de Cartagena y a los demás contenidos en la pregunta de vista, y trato y conversación.

98 Testigo. Fue preguntado por las preguntas generales de la ley, dijo ser de edad de cuarenta años y que no le tocan las preguntas generales.

2. A la segunda pregunta dijo que la sabe como en ella se contiene y la sabe porque la ha visto ser y pasar así como la pregunta lo dice.

100 3. A la tercera pregunta dijo que ha oído decir por cosa muy pública lo contenido en la pregunta y lo demás no lo sabe.

101 4. A la cuarta pregunta dijo que dice lo que dicho tiene y que es [14v] que de limosnas se ha sustentado y sustenta el dicho hospital.

102 5. A la quinta pregunta dijo que así lo vio este testigo como la pregunta lo dice en sede vacante siendo deán don Juan Pérez Materano y el canónigo Juan de Campos, que en aquella sazón los dichos deán y cabildo tenían el gobierno y administración del dicho hospital y en aquella sazón no entendió cosa en contrario.

6. A la sexta pregunta dijo que ha oído decir lo contenido en la pregunta públicamente en esta ciudad, y que este testigo vio que fue mayordomo del hospital en aquella sazón Diego Polo y lo demás no sabe.

104 7. A la séptima pregunta dijo que así lo ha oído decir públicamente en esta ciudad como la pregunta lo dice. 
8. A la octava pregunta dijo que no la sabe y que esta es la verdad por el juramento que hizo, y lo firmó de su nombre Francisco Sánchez. Ante mí, Juan de Meneses. Escribano.

107 En la ciudad de Cartagena, a diez y nueve días del mes de abril de mil y quinientos y setenta y siete años, el dicho Bartolomé de Arjona, vecino de esta ciudad para la dicha infor [15r] mación presentó por testigo a Juan Sánchez Mejía, vecino de esta ciudad del cual fue recibido juramento en forma debida de derecho y le hizo bien y cumplidamente, $\mathrm{y}$ siendo preguntado por las preguntas del dicho interrogatorio dijo lo siguiente:

1. A la primera pregunta dijo que conoce al dicho señor obispo de este obispado y al dicho Hernando de las Alas y a Juan de Baena y a Bartolomé de Arjona, y conoció al tiempo y sazón que aquí fue juez de residencia al doctor Juan de Maldonado y esto es lo que sabe.

Testigo. Fue preguntado por las preguntas generales de la ley, dijo que es de edad de más de cuarenta y cinco años y que no le toca ninguna de las preguntas generales de la ley.

110 2. A la segunda pregunta dijo que este testigo ve que al presente hace así como la pregunta lo dice y esto responde.

111 3. A la tercera pregunta dijo que este testigo sabe que dicho Hernando de Lipar, mi suegro, dejó al hospital cantidad de dinero con cargo que en cada un año se le diese ochenta misas como más cargo parecerá por cláusula de su [15v] testamento a que me refiero, y sabe asimismo que Juan Vásquez le dejó al dicho hospital unas casas que al presente tienen Pedro Mejía Mirabal y asimismo han dejado al dicho hospital y otras personas conforme a su posible, y que así de esto, como de la limosna ordinaria que se pide en esta ciudad los domingos, se sustenta el dicho hospital y esto responde.

112 4. A la cuarta pregunta dijo que dice lo que dicho tiene las preguntas anteriores de esta, y que este testigo no ha visto hacer donaciones al dicho hospital a ningún hombre lego y esto responde.

113 5. A la quinta pregunta dijo que este testigo vino a esta ciudad el año de cincuenta y bido (sic), como entonces no había obispo sino es sede vacante, nombraba el deán y cabildo, eran patrones del dicho hospital, y ponían mayordomo en él, y tomaban cuentas a los tales mayordomos, y esto responde.

114 6. A la sexta pregunta dijo que dice lo que dicho tiene en las preguntas antes de esta y esto responde.

115 7. A la séptima pregunta dijo que este testigo se acuerda de que el dicho doctor [16r] Maldonado, siendo gobernador y juez de residencia de esta dicha ciudad, quitó el patronazgo y administración del dicho hospital a los dichos deán y cabildo, y lo dio al cabildo de esta ciudad y desde entonces acá lo usa y es patrón de él el dicho cabildo, y que en lo demás que acerca de ello pasó se remite a lo que acerca de ello se escribió, y esto responde.

116 8. A la octava pregunta dijo que se acuerda este testigo que tuvo muchos dares y tomares el señor obispo don Juan de Simancas con el cabildo y justicia de esta dicha ciudad, acerca de que volviesen la administración del dicho hospital y que se remite a los autos que acerca de ello pasaron. 
117 9. A la novena pregunta dijo que lo que dicho tienen es la verdad y lo que sabe para el juramento que hecho tiene, y lo firmó de su nombre. Juan Sánchez Mejía. Ante mí, Juan de Meneses. Escribano. de esta santa iglesia y tenían puesto por mayordomo a Diego Polo, vecino de esta ciudad y este testigo, sirviendo por cura en la Iglesia, los dichos señores deán y cabildo le mandaron que en su nombre le tomase cuenta y se la tomó, a las cuales cuentas se remite, y que entiende este testigo que pues en aquel tiempo la tenía el deán y cabildo, que lo mismo sería todos los tiempos atrás, y así lo ha oído decir a algunas personas baquianas de este pueblo que los obispos pasados, don Jerónimo de Loaiza y don Francisco de Benavides, habían tenido siempre el patronazgo y administración del dicho hospital y esto sabe de la pregunta.

6. A la sexta pregunta dijo que [18v] dice lo que dicho tiene en la pregunta antes de esta, y que en cuanto a lo del doctor Juan Maldonado, que cuando vino a esta ciudad tenía la administración como dicho tiene el deán y cabildo de esta santa iglesia, y que el dicho Diego Polo era mayordomo por el deán y cabildo como tienen declarado, y así el dicho 
mayordomo, Diego Polo, pagaba por libramiento del deán y cabildo lo que se diera por el dicho hospital, y el dicho doctor Juan Maldonado se entrometió y se la quitó al dicho deán y cabildo como se ha visto, y la adjudicó a la justicia y regimiento de esta dicha ciudad, y que este testigo sabe que el dicho deán y cabildo reclamaron y requirieron con requerimiento no los despojase de la dicha administración, pues era suya, y no quiso desistirse de ello y este testigo fue el que ordenó los dichos requerimientos y esto es lo que sabe.

7. A la séptima pregunta dijo que dice lo que dicho tiene en las preguntas antes de esta y esto responde.

[18v] 8. A la octava pregunta dijo que sabe que el obispo don Juan de Simancas pretendió la dicha administración e hizo requerimiento al gobernador y cabildo, y aun le parece a este testigo que procedió por mandamientos y censuras contra las dichas justicias y regimiento para que se lo dejasen, y como el dicho señor obispo se fue, se quedó así, a los cuales papeles que sobre ello pasaron se remite y esto responde.

9. A la novena pregunta dijo que dice lo que dicho tiene, lo cual es la verdad. Y lo que sabe para el juramento que hecho tiene y lo firmó de su nombre. El Arcediano de Cartagena. Ante mí, Juan de Meneses. Escribano.

[Preguntas del interrogatorio preparado por Hernando de las Alas]

En Cartagena, en primero de abril de mil y quinientos y setenta y siete años, ante el muy ilustre señor gobernador y capitán general y por ante mí, el escribano yuso escrito, la presentó el contenido.

Por las preguntas siguientes sean examinados los testigos que fueren presentados por parte de Hernando de las Alas, procurador general de es [19r] ta ciudad, sobre la información que se ha ofrecido a dar para averiguar que el cabildo de esta ciudad es patrón del dicho hospital, nombrado señor San Sebastián de esta ciudad.

I. Primeramente, si conocen al dicho Hernando de las Alas y si saben que es procurador general de esta ciudad de Cartagena y si conoce al muy ilustre señor don fray Dionisio de Sanctis, obispo de esta ciudad y su gobernación.

II. Ítem, si saben, etcétera, que el dicho cabildo fundó el hospital y le dio sitio y solares con la autoridad que tiene de Su Majestad para lo poder hacer, que son los dichos solares a las espaldas de casas que fueron de Hernando de Lipar, las cuales el dicho cabildo y regimiento dieron a censo y tributo para renta del hospital.

III. Ítem si saben, etcétera, que para comprar las casas donde vive el médico del dicho hospital y sitio y solares donde ahora está hecho, dio Hernando de Lipar mil y quinientos pesos y para lo demás se han hecho limosnas, así de di [19v] funtos que lo han mandado en testamentos como otros vecinos de esta ciudad.

IV. Ítem, si saben estos que desde la fundación del dicho hospital ha estado en posesión este cabildo de esta ciudad de ser patrón y administrador, y nombrar mayordomo, y tomarle las cuentas sin que se haya entrometido el señor obispo ni los señores obispos pasados, ni les haya perturbado la dicha su posesión.

V. Ítem, si saben estos que los años pasados había como veinte años, poco más o menos, se quemó esta ciudad y la iglesia mayor que entonces había, y el gobernador que a la sazón era e[1] cabildo de esta ciudad, porque se rezasen y cantasen las horas, dieron orden que se pasasen al hospital entre tanto que la iglesia mayor se reedificara, y acabada de hacer se volvieron luego a ella y desocuparon el dicho hospital. Y en el 
tiempo que estuvieron no se entrometieron en la administración del señor obispo, [20r] que a la sazón era, ni clérigos, antes el dicho cabildo hizo en el dicho tiempo y hace de dicho oficio de patrón y administrador.

VI. Ítem, si saben, etcétera, que dicho cabildo y gobernadores que han sido han nombrado las personas legas que acostumbran pedir limosna un día de cada semana para el dicho hospital, de muy poco tiempo a esta parte se ha usado que en la iglesia mayor se nombren los que han de pedir la dicha limosna el tal día y antes de este tiempo el señor obispo ni legos no lo consentía.

VII. Ítem, si saben, etcétera, que el señor gobernador y gobernadores pasados y cabildo de esta ciudad han procurado siempre y procuran aumentos propios para el dicho hospital, así persuadiendo a que se le hagan limosnas como mandas y en testamentos como se han hecho y hacen.

VIII. Ítem si saben, etcétera, que cuando están flotas y armadas en el puerto de esta ciudad, que es la mayor parte del año, concurren enfermos, así marineros y gente de las dichas armada[s] en tanta cantidad como de Nombre [20v] de Dios, y de otras partes, y para la cura y sustento de los tales no basta la renta y propios del dicho hospital, y sale el dicho señor gobernador y regidores de dicho cabildo a buscar el remedio de los dichos pobres por la ciudad con tanto cuidado que ha acaecido en un día recogerse de limosnas trescientos y cuatrocientos pesos y muchas sábanas y lienzo y frazadas y colchones para los dichos pobres.

IX. Ítem, si saben, etcétera, que algunas mandas que particulares han hecho en testamentos para el dicho hospital, han sido con condición que dicho señor obispo ni los clérigos no se entrometan a usar oficio de patrón ni administrador de dicho hospital, y si se entrometiesen, por el mismo caso, revocan las dichas mandas, ni se entrometan a tomar cuenta al dicho hospital ni mayordomo de él de las propias, mandas y limosnas sino que solo quede al cabildo de esta dicha ciudad.

$\mathrm{X}$. Ítem si saben estos que los vecinos [21r] y moradores de esta ciudad son siempre muy continuos con sus limosnas para el dicho hospital por razón del cuidado que les tiene el señor gobernador y cabildo, y saben y entienden que si no fuese patrón, como lo es, faltarían las dichas limosnas y la mayor parte ellas.

XI. Ítem, si saben, etcétera, que los señores obispos ni clérigos que han sido ni son no han ayudado al dicho hospital con mandas y limosnas en testamentos ni fuera de ellos, ni en las ordinarias limosnas que se piden en el dicho hospital dan, ni ayudan para el sustento y cura de los dichos pobres.

144 XII. Ítem, si saben, etcétera, que dos años a esta parte se han labrado dos cuartos muy suntuosos dentro de los solares de dicho hospital, uno bajo y otro alto, para los enfermos que ocurren al dicho hospital, y una iglesia donde les dice misa todos los días, lo cual todo se ha pagado a cuesta de los vecinos y propios del dicho hospital, y se ha recogido y llegado con grande cuidado y diligencia del dicho señor [21v] gobernador y dado y cabildo, y para que la dicha obra no cesase y fuese adelante, Diego Daza, mayordomo que fue del dicho hospital, comenzó la dicha obra y la acabó supliendo de su hacienda tres o cuatro mil pesos, los cuales el dicho señor gobernador y cabildo han dado orden como se le paguen y recojan, así de limosnas que se han hecho y hacen como de los propias y rentas del dicho hospital.

XIII. Ítem, si saben, etcétera, que los pobres que morían en el dicho hospital antes que la dicha iglesia se hiciese, se enterraban en un solar que el dicho hospital tenía, que por 
no estar cerrado, habían en él muchas suciedades, lo cual se hacía porque los clérigos ni curas de la dicha iglesia mayor no los querían enterrar en su Iglesia sino les pagaban las sepulturas y entierros y así Jerónimo Rodríguez, vecino que fue de esta ciudad y otros vecinos se ofrecieron de pagar a los dichos clérigos la sepultura y entierro de los dichos [En pie de página: va tachado / y dado / no vale] [22r] pobres porque los recibiesen en la iglesia mayor y cementerio de ella.

XIV. Ítem, si saben, etcétera, que en los dichos dos cuartos y en la Iglesia del dicho hospital se habrá gastado más cantidad de ocho mil pesos sin que el dicho señor obispo ni clérigos hayan dado ni mandando cosa alguna para la dicha obra de dicho hospital. XV. Ítem, si saben, que pues el dicho hospital está fundado en esta ciudad de Cartagena, que es de Su Majestad y ayuda con sus limosnas y ha ayudado para el sustento de él, tiene la superioridad y señorío en él, por lo que sería grande inconveniente consentir que dicho señor obispo fuese patrón y administrador del dicho hospital.

XVI. Ítem, si saben, etcétera, que ha treinta años, poco más o menos, que dicho hospital se fundó por el cabildo de esta ciudad, como está dicho en las preguntas antes de esta, todo el dicho tiempo ha usado el dicho oficio de mayordomo y administrador el dicho cabildo.

[22v] XVII. Ítem, si saben, etcétera, que en el dicho hospital hay todo buen recaudo así de mayordomo como de negras que sirven a los dichos pobres y enfermos, como de médico y cirujano que los cura, y botica donde se recetan las medicinas, todo lo cual es visitado muy a menudo por el dicho señor gobernador y cabildo, y así anda todo en buen orden. Asimismo tiene el dicho cabildo de dicho hospital un clérigo de buena vida y costumbres, que cada día dice misa a los dichos pobres y los confiesa, y entierra los que se mueren en la Iglesia del dicho hospital.

XVIII. Ítem, si saben, etcétera, que todo lo susodicho es público y notorio y pública voz en esta ciudad, digan lo que saben, Hernando de las Alas.

ll señor gobernador lo recibió cuanto es in pertinente ${ }^{1}$ y mandó que por él se examinen los testigos Francisco Dalva y Pedro Mejía. Juan de Meneses. Escribano.

En ciudad de Cartagena, en trece días del mes de abril [23r] de mil y quinientos y setenta y siete años, ante el muy ilustre señor Pedro Fernández de Busto, gobernador y capitán general, y por ante mí, el escribano yuso escrito la presente. El contenido.

Muy ilustre señor Hernando de las Alas, procurador general de esta ciudad, en el pleito con el señor obispo sobre la información que pretende hacer sobre pertenecerle el patronazgo, hago presentación de estas preguntas de este interrogatorio por donde se examinen los testigos.

[Preguntas añadidas]

Porque vuestra merced pido y suplico las haya por preguntado y mándense examinen los testigos por ellas y con esta la recepción al escribano, y pido justicia y costas.

I. Si saben, etcétera, que después que se hizo y labró el hospital de esta ciudad, se tomó de nuevo la posesión el cabildo de esta ciudad en nombre de Su Majestad y de esta ciudad y se esculpieron en él las armas de Su Majestad y de esta dicha ciudad, digan lo que saben.

[23v] II. Ítem, si saben, etcétera, que todo lo susodicho es público y notorio, y pública voz y fama en esta ciudad, digan lo que saben, etcétera. Hernando de las Alas. 

Escribano. presentó el contenido. Meneses. Escribano. generales.

El señor gobernador los recibió cuanto es pertinente, y mandó que por él se examinen sus testigos. Juan de Meneses. Escribano.

[Probanza de los procuradores del cabildo de la ciudad]

Y después de lo susodicho en la dicha ciudad de Cartagena, en veinte y dos días del mes de abril de mil y quinientos y setenta y siete años, ante mí el escribano y testigo, pareció presente el dicho Mancio de las Cuevas, en el dicho nombre y presentó por testigos a Francisco Dalva y Lorenzo Martín, vecinos de esta dicha ciudad, de los cuales fue tomado y recibido juramento en forma según derecho, y ellos lo hicieron y prometieron de decir verdad, siendo presentes por testigos Mateo Hernández de Angulo y Francisco Gutiérrez, residentes en esta dicha ciudad. Juan de Meneses.

En la ciudad de Cartagena, en diez y nueve días del mes de abril de mil y quinientos y setenta y siete años, ante el muy ilustre señor [24r] Pedro Fernández de Busto, gobernador y capitán general, y por ante mí el escribano y testigos yuso escritos, la

Ilustre señor Mancio de las Cuevas, procurador del ilustre cabildo de esta ciudad, digo que en la información que el procurador general pretende hacer sobre ser patrón y administrador el dicho cabildo del hospital del Señor San Sebastián de esta ciudad, tengo de presentar por testigos a Francisco Dalva y a Lorenzo Martín, su padre, y a Diego Daza, mayordomo, que fue a los cuales he rogado muchas y diversas veces digan sus dichos en esta causa y no lo han querido y quieren hacer.

Porque a vuestra merced pido y suplico mande que un alguacil los traiga a decir sus dichos ante el presente escribano porque en otra manera yo no puedo hacer la dicha información y el tiempo se pasa y pido justicia. Mancio de las Cuevas.

El señor gobernador mandó que un alguacil los lleve a declarar ante mí. Juan de

[Testimonio de Pedro Mejía Mirabal]

[24v] En la ciudad de Cartagena, a diez y siete días del mes de abril de mil y quinientos y setenta y siete años, Mancio de las Cuevas, procurador, en nombre de la ciudad, presentó por testigo para la dicha información a Pedro Mejía Mirabal, alférez de infantería y vecino de la dicha ciudad, del cual fue recibido juramento en forma debida de derecho y se lo hizo bien y cumplidamente, y siendo preguntado por las preguntas del dicho interrogatorio y pregunta añadida, dijo y expuso lo siguiente:

167 1. A la primera pregunta dijo que conoce todos los contenidos en la pregunta y sabe este testigo que el dicho capitán Hernando de las Alas es procurador general de esta ciudad y lo sabe este testigo porque lo ha visto entrar muchas veces en los cabildos que se hacen en esta ciudad y pedir todo lo que conviene al bien y república de esta ciudad.

Testigo. Fue preguntado por las preguntas generales, dijo que es de edad de más de cuarenta años, poco más o menos, y que no le tocan ninguna de las preguntas

9 [25r] 2. A la segunda pregunta dijo que sabe este testigo que los señores del cabildo de esta ciudad y el señor gobernador dieron a tributo los dichos solares contenidos en la dicha pregunta y que los demás se remite a lo que sobre ello hay escrito porque este testigo no se halló en el tiempo que se repartieron los solares en esta tierra, más de que 
lo oyó decir por cosa pública que el cabildo de esta dicha ciudad dio los dichos solares para el dicho hospital y esto responde.

3. A la tercera pregunta dijo que sabe este testigo lo contenido en la pregunta porque es y pasa como en ella se contiene, porque este testigo ha visto el testamento que el dicho Hernando de Lipar hizo y la pasa que se hizo de la dicha casa por haber sido mayordomo del dicho hospital los años pasados y vio hacer parte de la dicha paga a Juan Sánchez Mejía, heredero del dicho Fernando de Lipar y asimismo vio muchas veces mandas que hicieron los señores del cabildo de esta ciudad y los demás vecinos para ayuda de él a acabar [25v] de pagar la dicha casa y esto responde.

4. A la cuarta pregunta dijo que sabe lo contenido en la pregunta como en ella se contiene, de doce años a esta parte que ha que este testigo vive en esta ciudad y ha dado cuentas del dicho hospital a las personas que el cabildo de ella las cometía sin haber visto lo contrario y ha visto en todo este tiempo ser administrador y patrón del dicho hospital al dicho cabildo y de su nombramiento este testigo fue mayordomo el año que fue nombrado para el efecto y esto responde.

5. A la quinta pregunta dijo que no la sabe porque en el en tiempo contenido en la pregunta este testigo no estaba en esta ciudad y esto responde.

6. A la sexta pregunta dijo que este testigo vio que se solía echar la limosna al mayordomo que era del dicho hospital a la puerta del gobernador que han sido en esta ciudad, y sabiendo que salían de la Iglesia los domingos, y que después años acá, porque parecía que lo to [En pie de página: va tachado/ en / no vale] [26r] maban por trabajo los mayordomos del dicho hospital, dan una cédula al sacristán para que allí sepan los que han de pedir la dicha limosna, lo cual se hizo de tres o cuatro años a esta parte, de voluntad y mandamiento del gobernador que a la sazón eran, y esto sabe de esta pregunta.

174 7. A la séptima pregunta dijo que sabe lo contenido en la pregunta por haber sido mayordomo del dicho hospital y que en el tiempo que este testigo fue mayordomo vino a esta ciudad los galeones de Pedro Meléndez, los cuales trajeron mucha cantidad de soldados enfermos en que de una vez sola se recibió en el dicho hospital noventa personas y de ahí para arriba, y que si no fuera por el favor y ayuda que este testigo tuvo del gobernador Francisco de Lugo, que a la sazón era, y de los demás señores del cabildo, no se pudieran recibir y curar tanta cantidad de ellos juntos de una vez, por ser como es muy pobre y de poca renta el dicho [26v] [repetido: el dicho] y que mediante su favor y ayuda, y limosnas de ellos y de los demás vecinos de este pueblo, los recibí y curé, así aquellos como otros muchos que después entraron, lo cual si así no se hiciera, murieran mucha cantidad de ellos por no curarse, y así de trescientos y setenta $u$ ochenta que recibí el año que yo fui mayordomo, no murieron sino diez, y esto sabe de esta pregunta.

8. A la octava pregunta dijo que sabe lo contenido en la dicha pregunta por haberlo visto ser y pasar así en el año que este testigo fue mayordomo y en otros tiempos de otros mayordomos, y esto responde de la pregunta.

9. A la novena pregunta dijo que sabe este testigo que algunas mandas que han hecho algunas personas al dicho hospital en sus testamentos es con la condición en la pregunta contenida, y lo sabe este testigo por lo haber visto en el libro del dicho hospital, donde están escritas las cláusulas y mandas de los dicho testa[27r] mentos y esto responde. 
177 10. A la décima pregunta dijo que este testigo ha visto siempre a los vecinos de esta ciudad ser continuos con sus limosnas al dicho hospital y que demás de serla y ser tan buena como lo es, parece que se animan mucho más a hacerlas por la mucha diligencia y cuidado que ven tener siempre a los gobernadores que en esta ciudad han sido, en especial al señor gobernador Pedro Fernández de Busto, que al presente es, y a la señora doña Micaela, su mujer, que siempre han tenido y tienen especial cuidado en salir a pedir por las calles limosna para el hospital, donde han recibido mucha cantidad de limosna y esto lo sabe porque lo ha visto y esto responde.

11. A las once preguntas dijo que sabe este testigo que el tiempo que fue mayordomo no vio ni entendió que hubiesen hecho limosna ninguna al dicho hospital ni mandas clérigo ninguno, ni las demás personas contenidas en la dicha pregunta, y esto responde.

[27v] 12. A las doce preguntas dijo que sabe lo contenido en la pregunta por haberlo visto ser y pasar como en la pregunta se contiene y vio este testigo andar al señor gobernador Pedro Fernández de Busto a pedir la dicha limosna a los vecinos de esta ciudad y a la señora doña Micaela, su mujer, por otra parte a las mujeres, donde juntaron mucha cantidad de limosna, y asimismo vio este testigo dar un libramiento al cabildo de esta ciudad al dicho Diego Daza, mayordomo, para que de los propios de él le diesen cierta cantidad de pesos para ayuda de la obra del dicho hospital que Diego Daza hizo y esto responde.

180 13. A las trece preguntas dijo que sabe este testigo que los dichos pobres que morían los enterraban en la parte que dice la dicha pregunta hasta tanto que el dicho Jerónimo Rodríguez y otras personas quedaron de pagar los entierros a los clérigos porque los enterrasen dentro de la Iglesia, y este testigo pagó a los [28r] dichos clérigos a tres pesos por todos los pobres que se enterraron en la dicha Iglesia y esto responde.

181 14. A las catorce preguntas dijo que este testigo le parece que se había gastado mucha cantidad de dineros en la Iglesia y cuarto alto y bajo que se ha hecho en el dicho hospital para los pobres por ser la obra buena y muy costosa, y que este testigo no ha visto ni entendido que el señor obispo ni los demás clérigos hayan dado cosa ninguna para ayuda la obra y esto responde.

182 15. A las quince preguntas dijo que sabe este testigo que Su Majestad ha ayudado y ayuda siempre con su limosna para el sustento del hospital porque cada año se le da de su Real caja el noveno y medio de los diezmos de esta ciudad, y que es cosa justa que Su Majestad tenga la superioridad y señorío en él, y que sería gran daño del dicho hospital e inconveniente consentir que el dicho señor obispo fuese patrón y administrador de él, y esto responde.

183 [28v] 16. A las diez y seis preguntas dijo que este testigo sabe y ha visto desde el tiempo que ha que este testigo está en esta ciudad, que puede haber doce o trece años, poco más o menos, siempre ha visto usar de él al mayordomo y administrador del dicho hospital al dicho cabildo y esto responde.

184 17. A las diez y siete preguntas, dijo que sabe lo contenido en la dicha pregunta por lo haber visto ser y pasar como la pregunta lo dice y sabe este testigo que se visita el dicho hospital cada sábado por la justicia y diputados del dicho cabildo para saber y inquirir si se curan y tratan bien los pobres que en él están y esto responde.

185 Y luego fue preguntado por la pregunta añadida. Dijo que este testigo haber visto en el dicho hospital estar esculpidas las armas de esta ciudad y que en lo demás se remiten a 
los autos que a cerca de la dicha posesión hubo y que esta es la verdad y lo que sabe para el juramento que hecho tiene y lo firmo de su nombre. Pedro Mejía Mirabal. Ante mi, Juan de Meneses. Escribano. 
213 4. A la cuarta pregunta dijo que [32r] sabe este testigo que desde que en esta ciudad está, que ha más de diez y siete años, no ha visto otra cosa en contrario de lo que la pregunta dice, sino que siempre el cabildo de esta ciudad ha sido siempre patrón y administrador de dicho hospital y cada año nombran mayordomo y a los que antes eran les toman cuenta sin que este testigo haya visto que ninguno de los señores obispos pasados se hayan metido en ello y perturbárselo, y esto sabe de esta pregunta.

214 5. A la quinta pregunta dijo que no la sabe más de haberlo oído decir, que al presente no se halló este testigo en esta ciudad, y esto responde.

215 6. A la sexta pregunta dijo que sabe este testigo que el señor obispo, don Juan de Simancas, pretendió ser patrón del dicho hospital y antes de esto se echaba la limosna cada domingo en la iglesia mayor porque los señores del cabildo le defendieron la posesión que pretendía del patronazgo del dicho hospital, mandó que no se echase la limosna como se solía hacer en la dicha iglesia mayor y por es [32v] ta razón el mayordomo que era del dicho hospital encomendaba cada domingo vocalmente a los vecinos de esta ciudad, y esto responde.

216 7. A la séptima pregunta dijo que lo sabe por haberlo visto ser y pasar así como la pregunta lo dice, y esto sabe de la pregunta.

217 8. A la octava pregunta dijo que la sabe por haberlo visto ser y pasar como la pregunta lo declara, y esto responde.

218 9. A la novena pregunta dijo que se remite este testigo a las mandas de los tales alegatorios, y esto responde.

219 10. A la décima pregunta dijo que sabe que cada domingo de todos los años que ha que este testigo está en esta dicha ciudad, se pide limosna para los pobres de esta ciudad, y los vecinos de ella hacen lo que pueden en este caso, y lo demás que la pregunta dice no lo sabe, y esto responde.

11. A las once preguntas dijo que no la sabe.

12. A las doce preguntas dijo que la sabe como ella se contiene porque el señor gobernador puso muy [33r] gran calor en ello y el mayordomo Diego Daza trabajó mucho y puso harta parte de su hacienda que el día de hoy se le de debe, y que este testigo ha oído decir que el señor gobernador y los señores del cabildo han dado orden como le pagar de las rentas y limosnas del dicho hospital, y de manera que no se deje de hacer caridad a los pobres, y esto responde de la pregunta.

222 13. A las trece preguntas dijo que sabe este testigo que cuando algún pobre moría, los enterraban en unos solares del dicho hospital porque allí había habido otro tiempo la Iglesia y estos eran los que no tenían con qué enterrarse en la iglesia, y los que tenían con qué, les pedían sus derechos los clérigos, y que este testigo oyó decir a Jerónimo Rodríguez que había mandado que se enterrasen los pobres en la iglesia mayor de esta ciudad y en el cementerio, y que pagaría los derechos, y esto sabe de la pregunta.

14. A las catorce preguntas dijo que [33v] en hacerse el dicho hospital como ahora está, y en lo que en él se habría gastado, me remito a la cuenta que Diego Daza ha dado como tal mayordomo, que la tengo por buena y verdadera, y que lo demás contenido en la pregunta este testigo no lo sabe.

224 15. A las quince preguntas dijo que ha oído decir este testigo que el dicho hospital se ha fundado con mandas que particulares han hecho, por donde parece que Su Majestad es 
verdadero Patrón, y en su nombre el ilustre cabildo de esta ciudad, y que se debe guardar lo que acerca de esto Su Majestad tiene ordenado y mandado, y esto responde.

16. A las diez y seis preguntas dijo que dice que dicho tiene en la pregunta antes de esta, y que en el tiempo que se fundó no sabe este testigo cosa alguna, y esto responde.

17. A las diez y siete preguntas dijo que sabe como la sabe como en ella se contiene por verlo muchas veces ser y pasar así como la pregunta dice, y esto responde.

ale al presente y muchos meses [34r] antes de ahora a que está allí un clérigo que se dice el Padre Escobar, de muy buena vida y fama, y que tiene mucha cuenta con los pobres y consolarlos y decirles misa y esto sabe de la pregunta.

228 Y luego fue preguntado por la pregunta añadida y dijo que este testigo ha visto y ve estar en la iglesia del dicho hospital pintadas las armas de esta ciudad, que Su Majestad le hizo merced en nombre y posesión que tiene el cabildo de ella de tal patrón en nombre de su Majestad como patrón general de todas las ayudas, y esto dijo que era la verdad y lo que sabe para el juramento que hecho tiene y lo firmó de su nombre. Bartolomé Sánchez. Ante mí, Juan de Meneses. Escribano.

[Testimonio de Lorenzo Martín]

230 Testigo. El dicho Lorenzo Martín, vecino de esta ciudad de Cartagena, testigo presentado para la dicha información por Mancio de las Cuevas, procurador, en nombre de su parte, y siendo preguntado por las preguntas del dicho interrogatorio y pregunta añadida, dijo lo siguiente:

231 [34v] 1. A la primera pregunta dijo que conoce a las partes contenidas en la pregunta de vista y trato y conversación, que con ellos ha tenido.

232 Testigo. Fue preguntado por las preguntas generales de la ley, dijo que es de edad de más de sesenta años y que no le toca ninguna de las preguntas generales.

2. A la segunda pregunta dijo que la sabe como en ella se contiene por haberlo visto ser y pasar como la pregunta lo dice.

234 3. A la tercera pregunta dijo que este testigo sabe cómo Hernando de Lipar dio más de mil pesos para comprar las dichas casas que la pregunta dice y lo demás dio Diego Polo y todos los demás vecinos de esta ciudad y esto responde.

235 4. A la cuarta pregunta dijo que de veinte años a esta parte que este testigo ha estado en esta ciudad, siempre ha visto ser patrón del dicho hospital al cabildo de esta ciudad y no ha visto cosa en contrario, y esto responde de la pregunta.

236 5. A la quinta pregunta dijo que la sabe por haberse hallado a todo lo que dicho el presente, $\mathrm{y}$ esto responde.

237 [35r] 6. De la sexta pregunta dijo que ha visto este testigo que de muy poco tiempo a esta parte se usa echar la limosna para el dicho hospital en la iglesia mayor de esta ciudad porque antes echaba la limosna el gobernador de esta ciudad y esto responde.

7. De la séptima pregunta dijo que la sabe por haberlo visto ser y pasar como la pregunta dice.

8. A la octava pregunta dijo que la sabe como en ella se contiene por haberlo visto ser y pasar como la pregunta lo dice.

9. A la novena pregunta dijo que no la sabe.

241

10. A la décima pregunta dijo que sabe que los vecinos de esta ciudad hacen muchas limosnas al dicho hospital y de lo demás dijo que no lo sabe, y esto responde. 

dice, $y$ esto responde. responde. Meneses. Escribano. lo siguiente: dice.

11. A las once preguntas dijo que la sabe.

12. A las doce preguntas dijo que la sabe como en ella se contiene por haberlo visto ser y pasar como la pregunta declara.

13. A las trece preguntas dijo que la sabe por haberlo visto ser y pasar como la pregunta

14. A las catorce preguntas dijo [En pie de página: va enmendado/ décima / vale] [35v] que sabe este testigo que se había gastado en la dicha obra más de dos mil pesos y de lo demás de la pregunta no lo sabe, y esto responde.

15. A las quince preguntas dijo que no la sabe.

16. A la diez y seis preguntas dijo que desde que este testigo ha que está en esta ciudad, siempre ha visto ser patrón del dicho hospital el cabildo de esta ciudad, y esto

17. A las diez y siete preguntas dijo que la sabe por haberlo visto ser y pasar como la pregunta lo dice, y esto responde.

Fue preguntado por la pregunta añadida dijo que antes y después ha estado en posesión el cabildo de esta ciudad y que ha visto en el dicho hospital pintadas las armas de esta ciudad y lo demás no lo sabe, lo cual dijo que era la verdad y lo que sabe de este caso para el juramento que hizo y lo firmó de su nombre. Lorenzo Martín. Ante mí, Juan de

\section{[Testimonio de Francisco Dalva]}

Testigo. El dicho Francisco Dalva, el escribano público [36r] y de cabildo de esta dicha ciudad de Cartagena, testigo presentado por el dicho Hernando de las Alas, habiendo jurado en forma y siendo preguntado por el dicho interrogatorio y preguntas de él, dijo

2 1. A la primera pregunta dijo que conoce a los en ella contenidos y sabe que el dicho Hernando de las Alas es procurador general de esta ciudad por que se halló presente en su elección en el ilustre Cabildo.

Testigo. Fue preguntado por las preguntas generales de la ley, dijo que es de edad de treinta y nueve años, poco más o menos, y que no es pariente ni enemigo de las partes ni le tocan ninguna de las preguntas generales de la ley.

2. A la segunda pregunta dijo que sabe que el cabildo de esta dicha ciudad tiene cédula de Su Majestad para que él y no otra persona alguna provea las tierras y solares que se hubieren de proveer en esta dicha ciudad, por lo cual este testigo cree y [36v] tiene por visto que el dicho cabildo dio y proveyó el sitio que dicho hospital tiene donde se fundó [por] el adelantado don Pedro de Heredia y así es verdad porque no lo pueda proveer otra ciudad conforme a la dicha cédula real que son en la parte y lugar que la pregunta

3. De la tercera pregunta dijo que sabe que el dicho Hernando de Lipar mandó, para comprar las casas y solares donde ahora está el dicho hospital, mil y cuatrocientos pesos y otras personas mandaron cantidad de cumplimiento de tres mil y tantos pesos y así las dichas casas se compraron y sitio y fundó en ellas el dicho hospital, lo cual sabe porque este testigo ha visto una memoria escrita de mano del licenciado Cepeda, oidor que a la sazón era del Nuevo Reino de Granada, a vecinos de esta gobernación, que pidió y demandó las dichas limosnas para el dicho efecto. 
256 4. A la cuarta pregunta dijo [En pie de página: va tachado/ ciudad / no vale] [37r] que este testigo a más de veinte años que ha estado residido en esta ciudad y sido en ella escribano del cabildo y público siempre del dicho tiempo a esta parte, visto que el cabildo, justicias y regimiento de esta ciudad han tenido el patronazgo y administración del dicho hospital y como tal se ha legado y nombrado en el día de año nuevo, entre los otros oficios, mayordomo del dicho hospital y diputados para tomar cuentas de los propios y rentas de él, sin que los obispos ni jueces eclesiásticos se hubiesen hallado presente ni han [con]sentido les entrometerse en ello, lo cual sabe porque lo ha visto ser y pasar así, y ha pasado ante este testigo.

5. La quinta pregunta dijo que este testigo se acuerda haber visto la iglesia catedral de esta ciudad en el dicho hospital el tiempo que no hubo en ella iglesia por haberse quemado y en el dicho hospital estuvo hasta tanto que se [37v] tornó a reedificar la iglesia, y a la sazón dicha administración del dicho hospital a la sazón este testigo no se acuerda quién la tenía, más de que cree y tiene por cierto que a causa de haber el deán don Juan Pérez Materano ser hombre muy caritativo y que hacía mucho bien a los pobres que era entonces el que gobernaba la Iglesia, tenía cuenta con la cura medicinal de los pobres que se llegasen al dicho hospital en el tiempo que allí estuvo la iglesia, y que después que la Iglesia se pasó a su lugar, volvió a tener cuidado de los pobres el cabildo, justicia y regimiento como lo ha tenido después acá, y esto responde a esta pregunta.

6. A la sexta pregunta dijo que sabe que el mayordomo, y algunas veces los gobernadores, solían encartar a personas que pidiesen limosna para el hospital de esta ciudad por el pueblo, y de poco tiempo a esta parte la echan la dicha limosna en la Iglesia de esta ciudad. [En pie de página: va tachado/ a la sazón / no vale]

[38r] 7. A la séptima pregunta dijo que sabe que los gobernadores y algunos de los del cabildo que han sido y son han tenido cuidado del aumento de los propios y rentas del dicho hospital y que se haga limosnas y han persuadido e insistido que hagan las dichas limosnas así en testamento como fuera de ellos, mostrando mucho deseo de que dicho hospital vaya siempre en aumento, lo cual sabe porque ha visto así pasar, como la pregunta lo dice.

260 8. A la octava pregunta dijo que al dicho hospital acude mucha cantidad de enfermos a curarse en flotas y fuera de ellas que a las veces no basta lo que el hospital tiene para los curar y regalar, y algunas veces, viendo esta necesidad, los gobernadores y personas del cabildo salen a pedir limosnas extraordinarias por el pueblo y llegan aunque los enfermos se acaban de curar y camas y sábanas y ropas y otros proveimientos para el dicho hospital con cuidado y mucha caridad que con el dicho hospital ha tenido y [38v] y tienen, lo cual así ha visto este testigo pasar.

261 9. A la novena pregunta dijo que sabe que algunos difuntos que se han muerto han mandado en la cláusula de sus testamentos algunas mandas al dicho hospital y algunos de ellos no quieren que el obispo ni prelado se entrometan en cosa de lo que mandan en el dicho hospital sino que el cabildo lo administre, lo cual sabe porque ante este testigo han pasado algunos testamentos a los cuales se remite.

10. A la décima pregunta dijo que sabe que los vecinos de esta ciudad hacen las limosnas ordinarias al dicho hospital un día de la semana que se pide para él, porque este testigo ha pedido algunas veces y se llega la limosna para ayuda[r] a curar los pobres, y que 
este testigo entiende que si los clérigos tuviesen la administración del dicho hospital, no se llegaría las limosnas con tan buena gana.

11. A las once preguntas dijo que este testigo no sabe que los clérigos hayan ayudado con limosnas en tes [39r] tamentos ni fuera de ellos al dicho hospital y que si hubieran hecho algunas limosnas, le parece a este testigo que lo hubiera sabido por la mano que tiene en los escribanos y otros ningunos de esta ciudad, y esto responde a ella.

12. A las doce preguntas y a las demás del dicho interrogatorio dijo que sabe que por orden del cabildo, se ha labrado el dicho hospital y hecha la Iglesia y la enfermería alta y baja, muy suntuosa, y esta es la verdad, y lo que sabe para el juramento que hizo y lo firmó de su nombre. Francisco Dalva. Ante mí, Juan de Meneses. Escribano.

[Notas de autentificación del documento]

Yo, Juan de Meneses, escribano de Su Majestad y mayor de esta gobernación, público de número de la ciudad. Por ausencia de Alonso de Nava, [En medio: Hechos testimonios de verdad] escribano propietario por nombramiento de la justicia y regimiento del dicho pedimento, y por mandado de los señores gobernador[es] que aquí firmaron [39v] nombre, y a ello interpuso su autoridad y derecho indicial. Lo hice escribir en estos treinta y nueve folios de papel y en fe de ello hice con mi signo [Signo] En testimonio de verdad: Juan de Meneses [rúbrica], escribano.

Nos, los escribanos de gobernación y público y de registro, que aquí firmamos, damos fe que Juan de Meneses, escribano, de quien va signado este testimonio, signó. Por el parecer es escribano de Su Majestad y usa el oficio de escribano y público provincial del superior, y a las escrituras que ante él pasan y consignados sus signos, les da fe y crédito en juicio y fuera de él. Hecha a veinte de mayo de mil y quinientos y setenta y siete años.

Luis Pérez de Vargas, [rúbrica] escribano Juan de Saldaña, [rúbrica] escribano de registro

\section{BIBLIOGRAPHY}

Fuentes

Archivo General de Indias:

Contaduría, 1380, N. 6. F. 109-112v.

Patronato 1, N. 40, R. 1; 27, R. 21, F. 4v; 193, R. 42; 197, R. 17, F. 71-72v; 282, N.1, R. 44.

Santafé 62, N. 3; 187, L. 2, FF. 35r; 228, N. 11; 987, L. 1, FF. 71-72; 78v; 987, L. 2, FF. 61v-62; 190-193; 208v; 212v; 987, L. 3, FF. 82-82v.

Santo Domingo 49, R. 8, N. 57 BIS, F. 10v.

Indiferente 773, N. 168.

Borrego, P. M. D. C. (1983). Cartagena de Indias en el siglo XVI (Vol. 288). Sevilla: Escuela de Estudios Hispano-Americanos, Consejo Superior de Investigaciones Científicas. 
Castellanos, J. (1997). Elegías de varones ilustres de Indias. Bogotá-Bucaramanga: Gerardo Rivas Moreno Editor.

Muñoz, R. J. (1880). Manual de paleografía diplomática española de los siglos XII al XVII: método teóricopractico para aprender á leer los documentos españoles de los siglos XII al XVII. Madrid: Imprenta de Moreno y Rojas.

Rivera, S. J. (2012). Aproximaciones a la concepción del cuerpo durante el período Colonial: evidencias arqueológicas de las prácticas quirúrgicas en dos hospitales de la orden de San Juan de Dios. Canto Rodado: Revista especializada en patrimonio, 7, 85-112.

Rojas, V. A. G. (2005). La paz interior. El testar como acto liberador. Siglo XVII. Fronteras de la Historia, 10, 187-210.

Tanodi, B. (2000). Documentos históricos. Normas de transcripción y publicación. Cuadernos de historia, Serie economía y sociedad, 3, 259-270.

Urueta, J. P. (1912). Cartagena y sus cercanías. Guía descriptiva de la capital del departamento de Bolivar. 2da. Ed. Cartagena: Tipografía Mogollón.

Urueta, J. P. (1887). Documentos para la historia de Cartagena, Tomo I. Cartagena: Tipografía de Antonio Araújo.

\section{NOTES}

1. La fórmula siempre dice "pertinente", pero en el original figura "yn pertinente".

\section{ABSTRACTS}

During the early colonial period, conflicts between civil and Church authorities over control of colonial institutions were quite frequent throughout Hispanic America. One such case, practically unknown to this day, was the one that faced Dionisio de Sanctis, Bishop of Cartagena de Indias, against members of the city council in 1577, as the prelate believed that the civil authorities had usurped the right to patronage and administer the hospital in San Sebastian from the ecclesiastical authorities. This work presents the transcription of the file of the lawsuit filed by the Bishop of Cartagena, something of great historical relevance because it allows us to know, firstly and from the local perspective, the strategies adopted by the Bishops in the solution of the conflicts that confronted them with the civil power, and secondly, to know the operation of the judicial system during the early colonial period. Likewise, some aspects, until now unexplored, of the history of the San Sebastian hospital and the Episcopal ministry of Dionisio de Sanctis are revealed.

Durante el período colonial temprano, los conflictos entre las autoridades civiles y eclesiásticas por el control de las instituciones coloniales fueron bastante frecuentes en toda la América hispana. Uno de esos casos, prácticamente desconocido hasta hoy, fue el que enfrentó a Dionisio de Sanctis, obispo de Cartagena de Indias, con los miembros del cabildo de esa ciudad en 1577, pues el prelado consideraba que las autoridades civiles habían usurpado el derecho de 
patronazgo y administración del hospital de San Sebastián a las autoridades eclesiásticas. Este trabajo presenta la transcripción del expediente del pleito interpuesto por el obispo de Cartagena, algo de gran relevancia histórica porque permite conocer, en primer lugar y desde la perspectiva local, las estrategias adoptadas por los obispos en la solución de los conflictos que los enfrentaban con el poder civil $\mathrm{y}$, en segundo lugar, el funcionamiento del sistema judicial durante el período colonial temprano. Asimismo, se revelan algunos aspectos, hasta ahora inexplorados, de la historia del hospital San Sebastián y del ministerio episcopal de Dionisio de Sanctis.

\section{INDEX}

Keywords: Dionisio de Sanctis, colonial hospitals, Cartagena de Indias, New Kingdom of Granada, justice administration

Palabras claves: Dionisio de Sanctis, hospitales coloniales, Cartagena de Indias, Nuevo Reino de Granada, administración de justicia

\section{AUTHOR}

\section{JOHN JAIRO MARÍN TAMAYO}

Laurntian University, Canadá

Correo electrónico: jmarintamayo@laurentian.ca 